\title{
UFRS 16 Kiralamalar Standardı Kapsamında Faaliyet Kiralamasının Kiracı İşletme Tarafından Muhasebeleştirilmesi ve Raporlanması
}

Ümmühan ASLAN *

\section{ÖZET}

Bir finanslama yöntemi olan kiralama işlemlerinin muhasebeleştirilmesi, ölçülmesi ve dipnot açıklamalarına ait düzenlemeler, Uluslararası Muhasebe Standartları Kurulu tarafindan yayımlanan UMS 17 Kiralama Isslemleri Standardında ele alınmıştır. Ancak 2016 yılının Ocak ayında ilgili kurul UMS 17 Kiralama işlemlerinin yerine UFRS 16 Kiralamalar Standardını yayınlamıştır. Yeni standart 2019 yılı Ocak ayında yürürlüğe girecek olup, UFRS 15 Müşteri Sözleşmelerinden Hasilatı uygulayan işletmelerin, bu standardı erken uygulamalarına izin verilmektedir.

2019 yılının Ocak ayında uygulamaya girecek olan UFRS 16 Kiralamalar Standardının, UMS 17 Kiralama Işslemleri Standardından ayrlan en önemli yanı, faaliyet kiralamalarının bilanço dipnotlarında değil varlık ve borçlarda muhasebeleştirilmesine yönelik olarak yapılan değişikliktir. Diğer bir ifade ile sadece finansal kiralama işlemleri değil, faaliyet kiralaması işlemleri de bilançoda raporlanacaktır. Bu uygulama ile kiralama işlemlerinin muhasebeleștirilmesinde tek bir model kabul edilmiş olmaktadır. Kiracı işletmelerin, varlık/kaynak ve gelir/ gider dengelerinde önemli değişikliklere neden olacağl ve bu değişikliklerden dolayl finansal göstergelerin de etkileneceği tahmin edilmektedir.

$\mathrm{Bu}$ çalışma, literatürde yapılan çalışmalardan farklı olarak, faaliyet kiralamalarının bilançoda raporlanması durumunda kiracı işletmelerin finansal tablolarının nasıl etkileneceğini, örnekler yardımı ile, ortaya koymayı hedeflemektedir. Yapılan çalışma sonucunda kiracı işletme, faaliyet kiralaması işlemlerini UFRS 16'ya göre raporladı̆̆ında, vergi, faiz ve amortisman öncesi karını (EBITDA), varlık ve kaynaklarını gerçeğe uygun ve şeffaf bir şekilde raporlayabilmektedir.

Anahtar Kelimeler: Faaliyet Kiralamalarl, Kiralama Muhasebesi.

JEL Sinıflandırması: M40, M48.

Operation Leases' Accounting And Reporting By Lessees And It's Effect On The Financial Statements (According To IFRS 16)

\section{ABSTRACT}

The arrangements for the recognition, measurement and disclosure of leases, which are a financing method, are addressed in IAS 17 Leases, issued by the international accounting standards board(IASB). However, in January 2016, the IASB issued the IFRS 16 Leases standard. The new standard will enter into force in January 2019 and businesses applying IFRS 15 Customer Contracts are allowed to implement this standard early.

The most important difference between the IFRS 16 leases standard, that will be implemented in January 2019, and the IAS 17 Leases standard is the change in accounting for operating leases not in balance sheet footnotes but in assets and liabilities. In other words, not only financial leases transactions but also operation leases transactions will be reported in the balance sheet. With this application, a single model has been adopted in accounting for leases. It is estimated that the lessees will cause significant changes in asset / liability and income / expense balances and will be affected in financial ratios due to these changes.

Unlike the studies in the literature, this study aims to reveal how the financial statements of the lessees will be affected if the operating leases are reported on the balance sheet, with the help of examples. The study reveals that the the lessees reports the operating lease transactions on the balance sheet and causes the earning before tax, interest and amortization (EBITDA) and asset and libialty to be reported in a fair value and transparent manner.

Keywords: Operational Leases, Leases Accounting.

Jel Classification: M40, M48.

\footnotetext{
*Doç.Dr.Ümmühan Aslan, Bilecik Şeyh Edebali Üniversitesi Uygulamalı Bilimler Yüksek Okulu, uaslan40@gmail.com
} 


\section{GíRiş̧}

İşletmelerin, hizmet ve mal üretmek için farklı tür ve çeşitte varlığa ihtiyaçları bulunmaktadır. İşletmelerin mal hizmet üretiminde ihtiyaçları olan varlıkları iki şekilde elde etme olanakları vardır. Bunlar satın alma ya da kiralamadır (tfageeks.com, 2017). Günümüz işletmelerinin birçoğunun, satın almadan ziyade kiralama yöntemini tercih ettikleri görülmektedir.

Kiralama, işletmelerin sermaye maliyetlerini düşürmek, daha fazla borçlanabilmek, vergi avantajı sağlayabilmek amacı ile başvurdukları bir finansman yöntemidir(Öztürk, 2016: 2). Özellikle, maliyetleri oldukça yüksek olan, makine, ekipman, hava aracı, bina, büyük yatırım gerektiren işletme donanımlarının, satın alınması yerine kiralanması tercih edilmektedir.

Kiralama kavram olarak, ekonomik bir varlığın kullanım hakkının kira ödemeleri karşılığında sahibi tarafından kullanıcıya devredilmesi olarak ifade edilmektedir (Sipahi, 2004: 3). Kiralamanın temel felsefesi, mülkiyet hakkının içerdiği kullanma, yararlanma ve yok etme yetkilerinden yalnızca yararlanma yetkisinin ekonomik olduğu varsayımına dayanmaktadır (Koç, 2004:3).

Henüz yürürlükte bulunan UMS 17 Kiralama İşlemleri Standardında, kiralama: kiraya verenin bir varlığın kullanım hakkını, bir ödeme veya ödeme planı karşılığında, taraflarca kararlaştırılmış bir zaman süresince kiracıya devrettiği sözleşmedir şeklinde tanımlanmıştır (UMS 17, Ek:4).

Yukarıda yapılan her iki tanımdan da anlaşılacağı gibi kiralama bir sözleşmedir. Bu sözleşme, kiracı olan işletmeye ilgili varlığın mülkiyet hakkını değil, kullanım hakkını vermektedir. Kullanım hakkı ise sözleşmede belirlenen zaman dilimi için geçerli olmaktadır.

Kiralama işlemleri kendi içinde, kiralanan varlığın mülkiyetine ilişkin risk ve yararların kiraya verende ya da kiracıda bulunma durumuna göre faaliyet kiralaması ve finansal kiralama olarak ikiye ayrılmaktadır. Bir varlığın mülkiyetine sahip olmaktan kaynaklanan risk ve yararların tamamının devredildiği kiralamalar, finansal kiralama olarak sınıflandırılır. Bir varlığın mülkiyetine sahip olmaktan kaynaklanan risk ve yararların tamamının devredilmediği kiralamalar ise faaliyet kiralaması olarak sınıflandırılır (UMS 17, EK:7).

Muhasebe tarafından üretilen mali bilgilerin, gerçeğe uygun, şeffaf ve tam bir şekilde raporlanması için çaba harcayan Uluslararası Muhasebe Standartları Kurulu, UMS 17 Kiralama İşlemleri Standardında yeniden düzenlemeye giderek, UFRS 16 Kiralamalar Standardını yayınlamıştır. Bu standart ile getirilen en önemli yenilik, daha önceden bilançoda raporlanmayan ancak bilanço dipnotlarında açıklanan faaliyet kiralama işlemlerinin bilançoda raporlanmasına ilişkin düzenlemedir.

UFRS 16'da yapılan bu düzenleme ile faaliyet kiralaması yapan işletmelerin, bilanço, gelir tablosu ve nakit akış tablolarında meydana gelecek olan değişimi değerlendirmeleri gündeme gelmiştir. Bilanço dışında tutulan ve işletmede kullanılan bu tür varlıkların 
bilançoda raporlanması ile işletmelerin aktif büyüklükleri ve borç yapıları değişecek ve dolayısıyla nakit akış tablosu da bu değişimimden etkilenecektir.

$\mathrm{Bu}$ çalışmada öncelikli olarak UFRS 16 Kiralamalar Standardına neden ihtiyaç duyulduğu ele alınmaktadır. Daha sonra faaliyet kiralamasının özellikleri açıklanmakta ve UFRS 16 Kiralamalar Standardı kapsamında faaliyet kiralamalarının bilançoda raporlanmasına ilişkin ilkeler açıklanmaktadır. Son bölümde ise faaliyet kiralamasının, UMS 17 Kiralama işlemleri ve UFRS 16 Kiralamalar Standardına göre muhasebeleştirme ve raporlama işlemleri örnekler yardımı ile açıklanarak iki standart arasındaki farklılığın, finansal tablola kalemlerine olan etkileri analiz edilmektedir.

\section{KİRALAMALAR STANDARTINDA DEĞİŞIKLIĞİN NEDENLERİ}

2005 yılında ABD Menkul Kiymetler ve Borsa Komisyonu (SEC), kira yükümlülükleri ile ilgili olarak mevcut standardın şeffaflığı sağlayamadığı konusunda endişelerini dile getirmişler ve eleştirilerde bulunmuşlardır. $\mathrm{Bu}$ eleştirileri değerlendiren Uluslararası Muhasebe Standartları Kurulu (IASB) ve Amerikan Finansal Muhasebe Standartları Kurulu(FASB), kiralama ile ilgili standardın yeniden geliştirilmesi sağlamak üzerine çalışmalarına başlamışlardır. 2014 yılı verilerine göre, IFRS ve Amerikan Genel Kabul Görmüş Muhasebe İlkelerine (US GAAP) uygun olarak düzenlenen finansal raporların dipnotlarında yaklaşık 3 trilyon dolar tutarında bilanço dışı kiralama yükümlülüklerinin olduğu tespit edilmiştir (IASB, 2016: 3).

Kiralama Standardına ait değişiklik çalışmaları 1996 yılına kadar uzanmakla birlikte, UFRS 16'yı esas alan çalışmalar 2006 yılında başlamış ve IASB ve FASB tarafindan yapılan toplantılar ve araştırmalarda bazı görüş ayrılıkları olmasına rağmen her iki organizasyon, faaliyet kiralaması konusunda tek bir muhasebe modelinin uygulanmasina ve faaliyet kiralamalarının bilançoya dahil edilmesi konusunda görüş birliğine varmışlardır.

Faaliyet kiralaması, bilanço dişı bir finansman aracıdır. Bilanço dışı finansman; şirketlerin faaliyetlerini sürdürmek amacıyla bilançolarının (finansal durum tablolarının) aktif ve pasifini etkilememek kaydıyla finansman bulmaları anlamına gelmektedir (Pamukçu 2010, 481-482). Bilanço dışı finansman, işletmenin mali yapısının, yatırımcılara, kredi verenlere güçlü görünmesine ve dolaysıyla daha fazla borçlanma olanağına sahip olmasına ve borçlanma giderlerinin artması neticesinde ise vergi avantajı sağlamasına neden olacağından tercih edilen bir yöntemdir (Öztürk, 2016: 3).

Faaliyet kiralamasının bilanço dışında kalması durumunda; kiracı işletmeler bir bakıma kiralamadan doğan borçlarını gizlemekte, işletme faaliyetlerine katkı sağlayan ve gelecekte işletmeye ekonomik fayda girişi saylayacak olan varlıklar, işletmenin varlıkları içinde yer almamakta ve kira ödemeleri faaliyet giderleri içinde gösterilerek vergi öncesi dönem karı azaltılmaktadır. Dolayısı ile finansal tablo kullanıcıları açısından ihtiyaca uygun, şeffaf ve karşılaştırılabilir bilginin sunulmasına engel olmaktadır (Öztürk, 2016: 3).

IASB'ın 2016 yılının Ocak ayında yayınlamış olduğu "Project Summary and Feedback Statement" başlıklı raporunda, kiralama yükümlülükleri ile ilgili finansal tablolardaki bilgi eksikliğinin büyüklüğü, ülkelere göre aşağıdaki gibi ortaya konulmuştur. 
Tablo 1. Faaliyet Kiralamasına Ait Bölgesel Oranlar

\begin{tabular}{|c|c|}
\hline \multicolumn{2}{|c|}{ Kiralama Yükümlülüklerinin Aktif Toplamına Göre Büyüklükleri } \\
\hline Afrika & $\% 27$ \\
\hline Asya Pasifik & $\% 32$ \\
\hline Avrupa & $\% 26$ \\
\hline Latin Amerika & $\% 45$ \\
\hline Kuzey Amerika & $\% 22$ \\
\hline
\end{tabular}

Kaynak: IASB Summary Project and Feedback Statement, January 2016

Dünya genelinde hisse senetleri borsada işlem gören IFRS veya US GAAP çerçevesinde raporlama yapan 30.000 şirketten 14.000'inde faaliyet kiralamasına rastlanmıştır. Faaliyet kiralamasına rastlanan başlıca sektörler; hava yolu taşımacılığı, turizm, perakendecilik ve taşımacılık sektörleri olup; bu şirketlerin bugünkü ve gelecekteki kira ödemelerinin toplam aktife oranları hesaplanmıştır (Öztürk, 2016: 3).

Yukarıda ifade edilen problemler sebebi ile ortaya çıkan bilgi eksikliği, yatırımcıların, analistlerin ve kredi veren kuruluşların işletmenin mali durumunu tam olarak anlamamalarına ve alacakları kararlarda yanlış karar vermelerine neden olacağı kaygısı ile UFRS 16 kiralamalar standardının oluşturulması çalışmaları başlatılmıştır ve 2016 yılında yeni standart yayınlanmıştır.

$\mathrm{Bu}$ yeni düzenlemenin en çok sermaye yoğun işletmelerden, telekomünikasyon, perakende ve ulaşım alanında faaliyet gösteren işletmeleri etkileyeceği beklenmektedir. Çünkü bu tür işletmeler satın alma yerine kiralama tercihinde bulunan işletmelerdir. Ancak günümüzde yüksek teknolojik yazılım kullanan, dışardan hizmet desteği alan işletmeler gibi "asset light" olarak adlandırılan işletmeleri çok fazla etkilemeyecektir (Poppleston,2017: 2).

\section{FAALIYET KIRALAMASININ ÖZELLIKLERI VE FINANSAL KÍRALAMA İLE ARASINDAKI FARKLILIKLAR}

Faaliyet kiralaması UMS 17 Kiralama işlemleri standardında ve 6361 sayılı, sayılı Finansal Kiralama, Factoring ve Finansman Şirketleri Birliği Kanunu'nun 3. maddesinde, finansal kiralama dışında kalan kiralamalar olarak ifade edilmiştir.

Bir başka tanımlamada, faaliyet kiralaması, mülkiyeti kiraya verende kalmak koşulu ile ekonomik ömründen daha kısa süre için kullanılmak üzere kira ödemeleri karşılığında yapılan kiralama türü olarak ifade edilmektedir (Ögülmüş, 1994: 6).

Tanımdan da anlaşılacağı üzere kiralamaya konu olan varlık, kiralama süresi sonunda sahibi diyebileceğimiz kiraya veren işletmeye devredilmektedir. Kiracı bu varlığı kiralama süresi içinde kullanma hakkına sahip olmaktadır. Bu bağlamda kiralamaya konu olan varlık bir başka işletmeye tekrar kiraya verilebilmektedir. Bu tür kiralamaların bir diğer özelliği ise, kiralama sürelerinin kısa olmasıdır.

Faaliyet kiralamasına konu olan varlıklara örnek olarak, dayanıklı tüketim malları, fotokopi makinaları, ulaşım araçları, örnek olarak verilebilmektedir (Ögüülmüş,1994: 6). 
Faaliyet kiralamasının bir diğer özelliği ise kiracıya sözleşme süresi bitmeden sözleşmeyi iptal edebilme yetkisinin verilmesidir. Kiracı böylelikle modası geçme ya da ihtiyacı kalmama gibi sebeplerle kira sözleşmesini iptal edebilir (Türko,1994: 338).

Aşağıdaki tabloda faaliyet kiralaması ile finansal kiralama arasındaki farklar belirtilmektedir. (Şentürk, 2016, s.624)

Tablo 2. Faaliyet ve Finansal Kiralama Arasındaki Farkl1lıklar(UMS 17’ye Göre)

\begin{tabular}{|l|l|}
\hline \multicolumn{1}{|c|}{ Finansal Kiralama } & \multicolumn{1}{|c|}{ Faaliyet Kiralaması } \\
\hline Dönem sonunda mülkiyet kiracıya devredilebilir & $\begin{array}{l}\text { Dönem sonunda kiraya konu olan varlık geri iade } \\
\text { edilir }\end{array}$ \\
\hline Orta uzun vadelidir & Kısa Vadelidir \\
\hline Kiralanan araç amortismana tabi tutulur & $\begin{array}{l}\text { Kiralanan araç ilk kiralama döneminde, kısmi } \\
\text { olarak amortismana tabi tutulabilir. }\end{array}$ \\
\hline $\begin{array}{l}\text { Banka veya Kiralama Şirketleri Bu Hizmeti } \\
\text { Sağlar }\end{array}$ & $\begin{array}{l}\text { İmalatçı veya tüccarın kendisi bu kiralama } \\
\text { hizmetini sunabilir. }\end{array}$ \\
\hline $\begin{array}{l}\text { Kiralama sözleşmesi bakım ve sigorta masrafları } \\
\text { hariç yalnızca mali konuları kapsar. }\end{array}$ & $\begin{array}{l}\text { Kiralama sözleşmesi bakım, sigorta ve temin } \\
\text { masraflarını kapsar. }\end{array}$ \\
\hline Bilançoya varlık olarak kaydedilir & Bilançoya kaydedilmez \\
\hline Faiz ve Amortisman Gideri vardır & Kira gideri vardır \\
\hline
\end{tabular}

Kiracı işletme açısından, her iki standart arasındaki farklar aşağıdaki tabloda gösterilmiştir. (Poppleston,2017,s.3)

Tablo 3. UMS 17 ile UFRS 16 Arasındaki Farklılıklar

\begin{tabular}{|l|l|l|l|}
\hline $\begin{array}{l}\text { Kiracı } \\
\text { Açısından }\end{array}$ & UMS 17 & UFRS 16 & Yorum \\
\hline Sinıflama & $\begin{array}{l}\text {-Finansal Kiralama } \\
\text {-Faaliyet Kiralama }\end{array}$ & Finansal kiralama & $\begin{array}{l}\text { Faaliyet kiralaması } \\
\text { finansal kiralama gibi } \\
\text { işleme alınacaktır. }\end{array}$ \\
\hline Bilançoda & $\begin{array}{l}\text {-Finansal Kiralama } \\
\text { Bilançoda } \\
\text {-Faaliyet kiralaması } \\
\text { dipnotlarda }\end{array}$ & $\begin{array}{l}\text { Tüm kiralamalar kiralama } \\
\text { maliyetleri üzerinden bilançoda } \\
\text { raporlanacaktır. }\end{array}$ & $\begin{array}{l}\text { Faaliyet kiralamaları da } \\
\text { bilançoda raporlanacaktır }\end{array}$ \\
\hline Tablosunda & Kiralama Giderleri & $\begin{array}{l}\text {-Amortisman Giderleri } \\
\text {-Kiralama Giderleri }\end{array}$ & $\begin{array}{l}\text { Faaliyet } \\
\text { azalmakta } \\
\text { Finansman } \\
\text { artmakta }\end{array}$ \\
\hline
\end{tabular}


UFRS 16 Kiralamalar standardının uygulanmaya başlayacağı tarih olan 2019 yılından önce işletmelerin mevcut faaliyet kiralamaları ile ilgili bazı hazırlıkları şimdiden yapmaları gerekmektedir (grantthornton.co.uk, 2017). Bunlar aşağıdaki adımlardan oluşmaktadır

- $\quad$ Bilançoda kiralama borcu, mevcut borçlardan ayrı olarak raporlanmalıdır.

- Gelecekte ödenecek olan kira giderlerinin bugünkü değeri ve olası kira ödemelerinin tahmini değeri hesaplanmalıdır. raporlanmalidir.

- Kiralanan varlık, "Kullanım Hakkı Olan Varlıklar" adı altında aktifte

- 12 aydan az veya 12 ay vadeli kiralamalar bilançoda raporlanmayacaktır ve gider muhasebeleştirilmeye devam edecektir. Dolayısıyla işletmeler, daha önce yapılmış ve 12 aydan daha uzun vadeli faaliyet kiralamalarını tespit etmeleri gerekmektedir.

- Faaliyet kiralaması kapsamında işletmede var olan ve düşük değere sahip olan, bireysel bilgisayarlar, tabletler ve telefonlar gibi varlıklar bilançoda raporlamayacaklardır.(bu varlıkların değer sınırı, 5000\$ ve altı olarak belirlenmiştir)( tfageeks.com, Mart 2017)

- Kiralamaya konu olacak olan varlığın maliyetinin belirlenmesinde ilgili varlığın yerleştirilmesi, sökülmesi takılması veya restorasyon maliyetleri ile ve eğitim maliyetleri dikkate alınmalıdır.

Bir başka kaynak ise yapılması gerekli olan hazırlık çalışmalarını aşağıdaki başlıklar altına sıralamıştır.(PWC,2016:1)

- $\quad$ Ortaklara bu durum bildirilmelidir

- Mevcut kurumsal kaynak p

- $\quad$ lanlaması, süreçler, kontroller ve veri durum analizi yapılmalıdır

- Mevcut kira sözleşmelerinin analizi yapılmalıdır

- $\quad$ Gömülü kiralamalar belirlenmelidir

- $\quad$ Şirket içerisinde etkilenecek tüm birimlerin belirlenmesi gerekir

- $\quad$ Farklı sektör uygulamaları ile durum analizi yapılmalıdır

- $\quad$ Şirket içerisindeki temel bilgiler toplanmalıdır

- $\quad$ Performans ölçümlerine ve finansal rasyolara olan etkileri değerlendirilmeli ve durum analizi yapılmalidır

Faaliyet kiralamasının bilançoda raporlanması sonucunda finansal tablolarda aşağıdaki durumlar söz konusu olacaktır.(tfageeks.com,2017) payı azalacaktır,

Varlık devir hızı azalacaktır, borçlanma artacak ve pasif içinde sermayenin

- $\quad$ Kayıtlı Borçlar, kayıtlı varlıklar, artacak

- Borç tutarı artacağı için kaynaklar toplamı içinde yabancı kaynakların payı artacaktır.

- $\quad$ Illk başlangıçta faiz gideri yüksek olacaktır.

- İzleyen dönemlerde değer düşüklüğü ve amortisman hesaplamasından dolayı ” Kullanım Hakkı Olan Varlıkların" değeri azalacaktır.

- $\quad$ EBITDA geçmiş yıllara göre daha iyi görünecektir 


\section{FAALIYET KİRALAMASI IŞLEMLERINIIN KİRACI AÇISINDAN MUHASEBELEŞTÍRILMESI VE ÖLÇÜLMESI}

Bu bölümde kiracı açısından, UMS 17 Kiralama işlemleri ve UFRS 16 Kiralamalar standardına göre faaliyet kiralamasına ait ilk kayda alma ve daha sonraki dönemlerde yapılacak ölçme işlemlerinin nasıl gerçekleştirildiği, örnekler yardımı ile ele alınmaktadır.

\section{1. İlk Muhasebeleștirme İşlemleri}

UMS 17'ye göre, faaliyet kiralamasında, yapılan kira ödemeleri doğrusal (eşit) olarak kiralama süresi boyunca gider olarak muhasebeleştirilmektedir (UMS 17: p.33).

Kira gideri eşit tutarlı olarak dönem giderine yansıtılmakta, bilançoya ilişkin herhangi bir işlem yapılmamaktadır.

UFRS 16'ya göre kiracı, kiraladığı kullanım hakk1 olan varlığını, maliyet değeri üzerinden kayda almaktadır. Maliyet bedeline dahil edilecek unsurlar ise şu şekilde siralanmıştır(UFRS 16, P: 24).

- $\quad$ Kira teşvikleri dişında kalan kira bedeli,

- Kiralamaya konu olan varlığın, taşınması, sökülmesi, restore edilmesi, yerleştirilmesi, montajı, konulacak yeri için yapılan tadilatlar gibi, kiracının kiralamanın başlangıcında katlandığı tüm maliyetler,

UFRS 16'ya göre kiracı işletmeler, yaptıkları faaliyet kiralamalarını aktifte "Kullanım Hakkı Olan Varlıklar", kiralama borcunu ise "Kiralama Borçları" gibi bir hesap adı altında diğer borçlardan ayrı olarak raporlanması gerekmektedir. Aşağıda kiracı işletmenin ilk kayda alma işlemlerine ait bir örnek olay verilmiştir.

Örnek Olay 1: A işletmesi, dağıtım ve pazarlama faaliyetlerinde kullanılmak amacı ile 10 adet kamyonu faaliyet kiralaması şeklinde kiralamıştır. Kiralama süresi 5 yıldır. Piyasa faiz oranı \% 5'dır. Kamyonetlerin toplam kiralama borcu 500.000 TL'dir. Kiralama borcunun bugünkü değeri ise 405.391 TL olarak hesaplanmıştır. Y1llık kira bedeli 100.000 TL'dir. UMS 17'ye göre ve UFRS 16'ya göre muhasebeleştirme işlemleri aşağıda gösterilmiştir. Bu kiralama için başlangıçta bir maliyetin yapılmadığı varsayılmıştır.

Analiz: Bu verilen örnek olayda, UMS 17'ye göre, bir muhasebeleştirme işlemi yapılmayacaktır. Ancak ilk yıla ait kira ödemesi kaydı başlangıçta yapıldığı için ilgili ödeme kaydı yapılarak ilgili gider hesabına ödenen kira bedeli aşağıdaki gibi kaydedilecektir.

\begin{tabular}{|l|l|l|l|}
\hline $\begin{array}{l}\text { Pazarlama Satış Dağıtım Giderleri } \\
\text { (Kiralama Giderleri Hs.) }\end{array}$ & 100.000 & \\
\hline & Kasa Hs. & & 100.000 \\
\hline Kira Bedelinin ödenmesi (UMS 17)
\end{tabular}




\section{UFRS 16'ya Göre İlk Muhasebeleştirme}

UFRS 16’ya göre verilen örnek olay için, öncelikle kiralanan kamyonete ait kiralama borcunun bugünkü değeri bulunmalıdır. Örnekde kiralama borcunun ilk muhasebeleştirme tarihindeki bugünkü değerinin $405.391 \mathrm{TL}^{1}$ olduğu ifade edilmiştir. Yıllık kira her yılın başında ödeneceği için ilk muhasebeleştirme tarihinde, ilk yılın kira bedeli peşin olarak 100.000 TL olarak ödenmiştir. Kiralanan kamyonet aşağıdaki kayıtta olduğu gibi 405.391 TL olarak aktifleştirilecektir.

\section{İlk Muhasebeleştirme Kaydı}

\begin{tabular}{|l|l|r|r|}
\hline Kullanım Hakkı Olan Varlıklar & & 405.391 & \\
\hline & $\begin{array}{l}\text { Kiralama Borçları } \\
\text { Kasa }\end{array}$ & & $305.391^{*}$ \\
& & \\
\hline $\begin{array}{l}\text { Kiralama Kaydı(UFRS 16) } \\
\text { *Kiralama Borçları kalemi içinde faiz ve anapara ayrımı dönem sonu işlemlerinde gösterilmiştir. }\end{array}$ \\
\hline
\end{tabular}

Yukarıdaki kayıtta kiralama borçlarının dönemsellik kavramı gereği kısa vadeli ve uzun vadeli olarak ayrıştırılması gerekmektedir. Burada anlatım kolaylığı olması için bu ayrım dikkate alınmamıştır.

\subsection{Sonraki Dönemlerde Ölçme İşlemleri}

UMS 17'ye göre kiracı işletme bir faaliyet kiralaması yapmış ise daha sonraki dönemlerde bir değerleme yapmasına gerek yoktur. Çünkü bilançoda değerlemeye konu olan bir varlık söz konusu değildir. Aktifte raporlanan bir varlık söz konusu olmadı̆̆ 1 için, amortisman ve değer düşüklüğü olması halinde değer düşüklüğü karşılığı hesaplamasına gerek bulunmamaktadır.

UFRS 16’ya göre Kiracı işletme kiraladı̆̆ 1 varlı̆̆ 1 , standartta belirtilen istisnalar haricinde ${ }^{2}$ maliyet de geri üzerinden ölçmesi gerekmektedir.

Kiracı işletme faaliyet kiralamasından kaynaklanan kiralama borcunu ise aşağıdaki şekilde ölçer ( UFRS 16, p.36)

a) Defter değerini, kira yükümlülüğündeki faizi yansıtacak şekilde artırır,

b) Defter değerini, yapılmış olan kira ödemelerini yansıtacak şekilde azaltır ve

\footnotetext{
1 Kira borucunun bugünkü değerinin hesaplanmasında kiralamadaki zımnî faiz oranı kullanılarak iskonto edilir. Kiracı, bu oranın kolaylıkla belirlenememesi durumunda, kiracının alternatif borçlanma faiz oranını kullanır.

${ }^{2}$ Yatırım amaçlı gayrimenkullerine TMS 40 Yatırım Amaçlı Gayrimenkuller 'de yer alan gerçeğe uygun değer yöntemini uygulaması durumunda, kiracı, TMS 40'ta verilen yatırım amaçlı gayrimenkuller tanımını karşılayan kullanım hakkı varlıklarına da söz konusu gerçeğe uygun değer yöntemini uygular. 35 Kullanım hakkı varlıklarının TMS 16'da yer alan yeniden değerleme yöntemini uyguladığı bir maddi duran varlık sınıfiyla ilişkili olması durumunda, kiracı, söz konusu maddi duran varlık sınıfıyla ilgili olan tüm kullanım hakkı varlıklarına yeniden değerleme yöntemini uygulamayı tercih edebilir.
} 
c) Defter değerini, tüm yeniden değerlendirmeleri ve yeniden yapılandırmaları yansıtacak şekilde ya da revize edilmiş özü itibarıyla sabit olan kira ödemelerini yansıtacak şekilde yeniden ölçer.

Kiracı kiraya konu olan varlığı, maliyet değeri üzerinden ölçtüğünde, ilgili varlığın amortisman ve değer düşüklüğünden sonra kalan değeri üzerinden raporlama yapacaktır.

Örnek Olay 2: Örnek olay 1'deki varlığın dönem sonundaki değeri maliyet bedeli üzerinden ölçüleceği varsayılmıştır. Bu değerleme yöntemine göre öncelikle ilgili varlığın aşağıdaki şekilde amortisman tutarı hesaplanacaktır. İlgili varlıkta bir değer düşüklüğü olmadığı varsayılmıştır.

UFRS 16'ya göre kiralanan kamyonetler için eşit paylı amortisman yöntemine göre 5 y1l kiralama süresi ve kullanma haklarının toplam değeri olan 409.391 TL üzerinden amortisman aşağıdaki gibi hesaplanacak ve muhasebeleştirilecektir.

Amortisman Kaydı

\begin{tabular}{|l|l|l|l|}
\hline Pazarlama Satış Dağıtım Giderleri & & $81.078^{*}$ & \\
\hline & $\begin{array}{l}\text { Birikmiş } \\
\text { Amortismanlar }\end{array}$ & 81.078 \\
\hline İk Yıl Amortisman Kaydı: $* \mathbf{4 0 5 . 3 9 1 / 5 = 8 1 . 0 7 8}$ & \\
\hline
\end{tabular}

Kiracı işletme ayrıca kiralama borcu için tahakkuk eden faiz giderini, ilgili borcun iskontolu değeri üzerinden belirlenen faiz oranı dâhilinde aşağıdaki gibi hesaplayarak muhasebeleştirecektir.

Faiz Kaydı

\begin{tabular}{|l|l|l|l|}
\hline Faiz Giderleri & & 15.270 & \\
\hline & Kiralama Borçları & & 15.270 \\
\hline \multicolumn{2}{|l|}{ Faiz Gideri Kaydı:305.391x0,05=15.270 } \\
\hline
\end{tabular}

\section{FAALIYYT KİRALAMASI İŞLEMLERINDE RAPORLAMA}

Yukarıdaki bölümlerde ifade edildiği üzere, yeni kiralama standardının en göze çarpan düzenlemesi, faaliyet kiralama işlemlerinin bilançoya dâhil edilmesidir. Bu düzenleme ile faaliyet kiralamasına konu olan varlıklar bilançoda, duran varlıklar grubunda, maddi duran varlıklar veya maddi olmayan duran varlıklar grubunda "Kullanım Hakk Olan Varlıklar" olarak faaliyet kiralaması borçları ise, borçlardan ayrı bir başlık olarak ya da borçlar içinde "Kiralama Borçları" olarak raporlanmaktadır. Gelir tablosunda, faaliyet kiralamasına konu olan varlığın amortisman gideri ve faiz gideri raporlanmalıdır. Standarda göre, kira borçlarına ait ödemeler, nakit akış tablosunda, finansal faaliyetlerden doğan nakit akışı grubu içinde raporlanacaktır. Değişken kira ödemeleri ve kısa vadeli kiralama borçları ise nakit akım tablosunda işletme faaliyetlerinden nakit akışları bölümünde gösterilmelidir (BDO Practice, 2016: 45). 
Faaliyet kiralamalarının bilançoda raporlanmasının bilanço ve gelir tablosuna olan etkisi aşağıdaki örnek olay üzerinde açıklanacaktır.

Örnek Olay 3: A işletmesi, 01.01.2017 tarihinde dağıtım ve pazarlama faaliyetlerinde kullanılmak amacı ile 10 adet kamyonu faaliyet kiralaması şeklinde kiralamıştır. Kiralama süresi 4 yıldır. Piyasa faiz oranı $\% 5$ 'dır. Kamyonetlerin toplam kiralama borcu 240.000 TL'dir. Bu borcun bugünkü değeri ise 212.900 TL olarak hesaplanmıştır. Y1llık Kira bedeli 60.000 TL'dir. UMS 17'ye göre ve UFRS 16'ya göre muhasebeleştirme işlemleri aşağıda gösterilmiştir. Bu kiralama için başlangıçta bir maliyete katlanılmadığı varsayılmıştır.

Dönem sonu itibari ile bu faaliyet kiralamasına konu olan varlığın yıllara göre amortisman tutarları eşit paylı amortisman yöntemine göre aşağıdaki gibi hesaplanacaktır.

\begin{tabular}{|l|c|c|c|}
\hline Yıl & Maliyet Değeri & Amortisman Tutarı & Kapanış Değeri \\
\hline 1.Yıl & 212.900 & 53.225 & 159.675 \\
\hline 2. Yıl & 159.680 & 53.225 & 106.455 \\
\hline 3.Yıl & 106.450 & 53.225 & 53.225 \\
\hline 4.Yıl & 53.230 & 53.225 & \\
\hline
\end{tabular}

Sabit kira ödemesi olan 60.000 TL gelir tablosuna yansıtılacaktır. Aşağıdaki tabloda, y1llara göre, kullanım hakkı varlıklar ve kiralama borcuna ait tutarlar ve kira giderine ait faiz tutarları görülmektedir.

\begin{tabular}{|l|c|l|c|c|c|}
\hline Yıl & $\begin{array}{l}\text { Açılış Defter } \\
\text { Değeri }\end{array}$ & $\begin{array}{l}\text { Taksit } \\
\text { Tutarı }\end{array}$ & Ana Para & Faiz & $\begin{array}{l}\text { Kapanış Defter } \\
\text { Değeri }\end{array}$ \\
\hline 1.Y1l & 212.900 & 60.000 & 48.550 & 11.450 & 164.350 \\
\hline 2.Y1l & 159.675 & 60.000 & 51.540 & 8.460 & 108.135 \\
\hline 3.Y1l & 106.455 & 60.000 & 54.720 & 5.280 & 51.735 \\
\hline 4.Y1l & 53.225 & 60.000 & 58.100 & 1.910 & \\
\hline
\end{tabular}

Aşağıdaki yıllara göre bilançolarda görüldüğü üzere başlangıç tarihinde kullanım hakları varlıkları ve kira borcu tutarları 212.900 TL olarak raporlanmıştır.

İkinci yılda hesaplanan amortisman tutarı kadar "Kullanım Hakları Olan Varlıklar" hesabında azalma olmuştur. Diğer bir ifade ile kiralanan varlığın maliyet değeri olarak kabul edebileceğimiz 212.900 TL'den amortisman tutarı olan 53.225 TL düşülmüş ve bilançoda 159.675 TL olarak sunulmuştur. Kira Borcu ise, 212.900 TL'den sabit kira ödemesi olan 60.000 TL düşülmüş 11.450 TL'lik faiz tutarı eklenerek ve 164.350 TL olarak raporlanmıştır.

Diğer yıllardaki faaliyet kiralaması varlık ve borçları aynı şekilde hesaplanarak aşağıdaki şekilde raporlanmıştır. 


\begin{tabular}{|c|c|c|c|}
\hline \multicolumn{4}{|c|}{ Başlangıç } \\
\hline Kullanım Hakkı & 212.900 & Kira Borcu & 212.900 \\
\hline \multicolumn{4}{|c|}{ 1. Yıl Bilançosu } \\
\hline Kullanım Hakkı & 159.675 & Kira Borcu & 164.350 \\
\hline \multicolumn{4}{|c|}{ 2. Yıl Bilançosu } \\
\hline Kullanım Hakkı & 106.455 & Kira Borcu & 108.135 \\
\hline \multicolumn{4}{|c|}{ 3. Yıl Bilançosu } \\
\hline Kullanım Hakkı & 53.225 & Kira Borcu & 51.735 \\
\hline \multicolumn{4}{|c|}{ 4. Yıl Bilançosu } \\
\hline Kullanım Hakkı & 0 & Kira Borcu & 0 \\
\hline
\end{tabular}

Aşağıdaki tabloda ise ilgili faaliyet kiralamasına ait giderlerin UFRS 16 ve UMS 17 'ye göre gelir tablosuna olan yansıması gösterilmektedir. ${ }^{3}$

\begin{tabular}{|c|c|c|c|}
\hline \multicolumn{2}{|c|}{ GIDERLER(UFRS 16) } & \multicolumn{2}{|c|}{ GIDERLER (UMS 17) } \\
\hline Amortisman Gideri & 53.225 & \multirow{3}{*}{ Kira Giderleri } & \multirow{3}{*}{60.000} \\
\hline Faiz Gideri & 11.450 & & \\
\hline 1.YIL & 64.675 & & \\
\hline Amortisman Gideri & 53.225 & \multirow{3}{*}{ Kira Giderleri } & \multirow{3}{*}{60.000} \\
\hline Faiz Gideri & 8.460 & & \\
\hline 2.YIL & 61.685 & & \\
\hline Amortisman Gideri & 53.225 & \multirow{3}{*}{ Kira Giderleri } & \multirow{3}{*}{60.000} \\
\hline Faiz Gideri & 5.280 & & \\
\hline 3.YIL & 58.505 & & \\
\hline Amortisman Gideri & 53.225 & \multirow{3}{*}{ Kira Giderleri } & \multirow{3}{*}{60.000} \\
\hline Faiz Gideri & 1.910 & & \\
\hline 4.YIL & 55.135 & & \\
\hline & Toplam: 240.000 & & lam: 2 \\
\hline
\end{tabular}

\footnotetext{
${ }^{3}$ https://www.tebarval.com.tr/tr/arac-filo-kiralama/haberler/ufrs16-yeni-muhasebe-standardi, örneğinden uyarlanmıştır
} 
Yukarıdaki tablodan anlaşılacağı üzere, UFRS 16'ya göre yapılan raporlamanın, finansal tablo kullanıcılarına, işletmenin faaliyet kiralama işlemleri hakkında doğru, güvenilir ve gerçeğe uygun raporlama yapılmasına hizmet ettiği görülmektedir.

UFRS 16'ya göre yapılacak raporlamada, faaliyet kiralamasına konu olan bir varlıklar bilançoya yansıtılmaktadır. Uluslararası Muhasebe Standartlarına göre bir varlığın bilançoda raporlanabilmesi için, ilgili varlığın, işletmenin faaliyetlerine katkı sağlaması, gelecekte işletmeye ekonomik bir girdi sağlayacak olması ve değerinin ölçülebiliyor olması gerekmektedir. Yukarıdaki örnekten de anlaşılacağı üzere, kiralamaya konu olan kamyonetler, işletmenin faaliyetlerinde kullanılmakta, varlık için katlanılan bedel ölçülebilmekte ve bu varlığın gelecekte işletmeye katkı sağlayacağ 1 beklentisi bulunmaktadır. Diğer bir ifade ile ilgili varlığın, mülkiyetinin başkasına ait olması yukarıdaki açıklanan gerçeklerin yok sayılmasına neden olamayacağı için, yapılan son düzenleme, UFRS'lerin temel amacına uygun bir düzenleme olarak karşımıza çıkmaktadır.

Faaliyet kiralamasının bilanço içine alınmasından sonra işletmelerin faiz, vergi ve amortismandan önceki kar rakamı olan EBITA üzerine etkisi ise aşağıdaki örnekte açıklanmaktadır.

Örnek Olay 3: İşletme, bir alış veriş merkezini 5 yıllı̆̆ına kiralamıştır. Yıllık kira bedeli 75.000 TL'dir. Faiz oranı \%5'dir. Faaliyet kiralamasına konu olan varlığa ait kiralama borcunun bugünkü değeri 324.711 TL'dir. Bu işletmenin her yıl 100.000 TL satış karı elde edeceği ve başka giderleri ve gelirinin olmayacağı varsayılmaktadır.

$\mathrm{Bu}$ işletmenin faaliyet kiralamasını, bilançoda raporlaması ve raporlamaması durumunda net kar ve EBITDA rakamlarının nasıl etkileneceği aşağıda gösterilmiştir.

\begin{tabular}{|c|c|c|c|c|c|c|c|c|}
\hline & \multicolumn{4}{|c|}{ UMS 17} & \multicolumn{4}{|c|}{ UFRS 16} \\
\hline Yil & Amort. & Faiz & Kira & Net Kar & Amort. & Faiz & Kira & $\begin{array}{l}\text { Net } \\
\text { Kar** }\end{array}$ \\
\hline 1.Y1l & - & - & 75.000 & $25.00 *$ & 64.942* & $16.235^{* *}$ & 75.000 & 18.825* \\
\hline 2.Y1l & - & - & 75.000 & 25.000 & 64.942 & 13.297 & 75.000 & 21.761 \\
\hline 3.Y11 & - & - & 75.000 & 25.000 & 64.942 & 10.212 & 75.000 & 24.846 \\
\hline 4.Y11 & - & - & 75.000 & 25.000 & 64.942 & 6.972 & 75.000 & 28.086 \\
\hline $5 . Y_{11}$ & - & - & 75.000 & 25.000 & 64.942 & 3.571 & 75.000 & 31.487 \\
\hline & & & 375.000 & 125.00 & 324.711 & 50.289 & 375.000 & 125.000 \\
\hline \multicolumn{5}{|c|}{ *Satışlar- Kira Gideri= 100.000-75.000 } & \multicolumn{4}{|c|}{$\begin{array}{l}\text { *Amortisman Tutarı= 324.711/5 } \\
* * \text { Faiz= 324.711TL üzerinden, } \% 5 \text { faiz oranı ve } 5 \\
\text { yıl vade üzerinden Excelde hesaplanmıştır) } \\
* * * \text { Net Kar= Satıslar-( Amortisman+ Faiz) }\end{array}$} \\
\hline
\end{tabular}


Yukarıdaki tablodan görüldüğü üzer, işletmenin UMS 17'ye göre net karı her yıl 25.000 TL olarak gelir tablosunda raporlamaktadır. UFRS 16'ya göre, işletmenin her y1l kar rakamının faklı olduğu, ilk yıllarda karın düşük daha sonraki yıllarda karın yüksek olduğu görülmüştür. Aşağıdaki tabloda ise UMS 17 VE UFRS 16'ya göre EBITDA rakamları gösterilmektedir. UMS 17'da EBITDA tutarlarının UFRS 16'ya göre hesaplanan EBITDA tutarlarından daha düşük olduğu görülmektedir. Bu bağlamda işletmeler için önemli olan kiralama işlemlerinin finansal raporlarda sunumları da bir o kadar önem taşımaktadır.

\begin{tabular}{|c|c|c|}
\hline Yıl & $\begin{array}{c}\text { UMS 17'ye Göre } \\
\text { EBITDA }\end{array}$ & $\begin{array}{c}\text { UFRS 16'ya Göre } \\
\text { EBITDA }\end{array}$ \\
\hline 1.Y1l & 25.000 & 100.000 \\
\hline $2 . Y_{1} 1$ & 25.000 & 100.000 \\
\hline $3 . Y_{11}$ & 25.000 & 100.000 \\
\hline $4 . Y_{1} 1$ & 25.000 & 100.000 \\
\hline $5 . Y_{11}$ & 25.000 & 100.000 \\
\hline
\end{tabular}

\section{SONUÇ:}

Günümüzde işletmeler, faaliyetlerinde kullandıkları birçok makine, taşıt ve ekipmanı satın almak yerine kiralamaktadırlar. Yapılan araştırmalar, işletmelerin aktiflerinin \%20'si ila \%30’u oranında kiralama yaptıklarını ortaya koymaktadır.

Kiralama işlemlerinin kaydedilmesi ve raporlanmasına yönelik olarak Uluslararası Muhasebe Standartları Kurulu UMS 17 Kiralama İşlemleri Standardının yerini alacak olan UFRS Kiralamalar Standardını 2016 yılının Ocak ayında yayınlamıştır. UFRS 16 Kiralamalar Standardı 2019 yılı ocak ayında yürürlüğe girecek ve UMS 17 yürürlükten kaldırılacaktır.

$\mathrm{Bu}$ çalışmada faaliyet kiralamasının muhasebeleştirilmesi ve raporlaması ile ilgili iki standart arasındaki farklar örnekler yardımı ile ortaya konulmuştur.

UMS 17 Kiralama İşlemleri Standardının tam tersine, UFRS 16 Kiralamalar Standardına göre faaliyet kiralamalarının bilançoda raporlanması gerekmektedir. $\mathrm{Bu}$ düzenlemeden, özellikle taşıma aracı, ekipman, makine kiralaması yaparak faaliyetlerini devam eden hava taşımacılığı işletmeleri, perakende işletmeler, telekomünikasyon işletmelerinin daha çok etkileneceği tahmin edilmektedir. Çünkü en fazla faaliyet kiralaması yapan işletmeler bu tür işletmelerdir.

Yeni düzenlemenin, işletmenin, faiz vergi ve amortisman öncesi karın(EBITDA), kaynak yapısı içinde borç oranın, amortisman ve finansman giderlerinin artmasına neden olduğu örneklerde gösterilmiştir. Bu standardın uygulanmaya başlaması ile diğer işletmelere göre daha fazla faaliyet kiralaması yapmış olan işletmelerin, mali yapı oranları yüksek, cari oranları düşük çıkacaktır. 
$\mathrm{Bu}$ çalışmanın faaliyet kiralaması yapan işletmelere, geçiş aşaması olan 2019 yılına kadar neler yapmaları gerektiği konusunda, yol gösterici olarak katkı sağlayacağı düşünülmektedir.

Bundan sonra yapılacak çalışmalarda, sektörel veriler dahilinde yeni düzenlemenin etkisinin nasıl olacağının ortaya konulmasının literatüre ve uygulamacılara katkı sağlayacağı kanaatine varılmıştır.

\section{KAYNAKLAR}

ÖZTÜRK, Can,(2016),’UFRS 16 Kiralama İşlemleri Standardının Eski UMS 17 Standardı ile Karşılaştırılması ve Almanya ve Türkiye'de Hisse Senetleri Halka Açık Olan Hava Yolu Şirketlerinin Finansal Durumuna Etkisi, Muhasebe Bilim Dünyası Dergisi”, 18/1

KOÇ, Mehmet, (2004), “Finansal Kiralama (Leasing)”, Beta Yayınları, İstanbul.

SİPAHİ, Barış, (2004), “Leasing İşlemleri ve Muhasebesi”, Türkmen Kitabevi, İstanbul.

ŞENTÜRK, Fatih ,(2016),” Türk Vergi Mevzuatı Kapsamında Faaliyet Kiralaması Yapan İşletmelerde Muhasebe Uygulamaları,’ Journal of Bussines Research- Turk, Sayı:8/1

ÖĞÜLMÜŞ, Levent (1994),’'Leasing”, T. İş Bankası A.Ş. Genel Müdürlüğü-İktisadi

Araştırma Müdürlüğü, Ankara.

https://ownet.co.uk/author/richardpoppleton (22.10.2017)

http://www.ifrs.org/-/media/project/leases/ifrs/published-documents/ifrs16-projectsummary.pdf ( 10.10 .2017$)$

https://www.pwc.com.tr/tr ( 24.10.2017)

https://www.bdo.global/getattachment/Services/Audit-Assurance/IFRS/IFRS-inPractice/IFRS16IP_Leases_print.pdf.aspx?lang=en-GB ( 23.10.2017)

http://tfageeks.com/accounting-leases-ifrs-16-vs-ias-17 ( 24.10.2017)

https://www.tebarval.com.tr/tr/arac-filo-kiralama/haberler/ufrs16-yeni-muhasebe-standardi/ ( 18.10.2017) 